\title{
FENOMENA MASALAH BULLYING DI SEKOLAH
}

\author{
Endang Retnoningsih \\ Email : endangretningsih72@gmail.com
}

\begin{abstract}
Abstrak : Banyak sebab peserta didik melakukan perilaku bullying. Penelitian ini membahas tentang motif rasa aman peserta didik melakukan perilaku bullying di Sekolah. Beberapa konsep perilaku sosial digunakan untuk menganalisis bagaimana praktek bullying terjadi, apa saja motiv dan bagaimana praktek bullying itu dimaknai oleh pelaku. Penelitian ini bertujuan untuk mengetahui bentuk-bentuk perilaku bullying, makna bullying bagi para pelaku bully, serta faktor pendorong terjadinya perilaku bullying dilingkungan sekolah. Kajian ini menggunakan metode studi literature. Hasil penelitian menunjukkan fakta bahwa; pertama, sikap apatis dari lingkungan menyebabkan angka bullying semakin tinggi di lingkungan sekolah. Kedua, keseluruhan pelaku bullying merupakan korban, sehingga korban berubah menjadi seorang pelaku bullying. Ketiga, tujuan korban menjadi pelaku bullying adalah untuk melindungi diri, serta untuk mendapatkan rasa aman dari ligkungannya. Selain itu pelaku juga melakukan bully untuk tujuan membalaskan dendamnya, hal ini karena pelaku pernah menjadi korban. Balas dendam tersebut berupa peniruan dari perlaku yang diterimanya.
\end{abstract}

Kata Kunci : Kasus, Bullying, dan Sekolah

\section{PENDAHULUAN}

Masa remaja merupakan suatu fase perkembangan antara masa kanak-kanak dan masa dewasa. Dimana pada masa ini remaja memiliki kematangan emosi, sosial, fisik dan psikis. Remaja juga merupakan tahapan perkembangan yang harus dilewati dengan berbagai kesulitan. Dalam tugas perkembangannya, remaja akan melewati beberapa fase dengan berbagai tingkat kesulitan permasalahannya sehingga dengan mengetahui tugas-tugas perkembangan remaja dapat mencegah konflik yang ditimbulkan oleh remaja dalam keseharian yang sangat menyulitkan masyarakat, agar tidak salah persepsi dalam menangani permasalahan tersebut. Pada masa ini juga kondisi psikis remaja sangat labil. Karena masa ini merupakan fase pencarian jati diri. Biasanya mereka selalu ingin tahu dan mencoba sesuatu yang baru dilihat atau diketahuinya dari lingkungan sekitarnya, mulai lingkungan keluarga, sekolah, teman sepermainan dan masyarakat. Semua pengetahuan yang baru diketahuinya diterima dan ditanggapi oleh remaja sesuai dengan kepribadian masing-masing. Disinilah peran lingkungan sekitar sangat diperlukan untuk membentuk kepribadian seorang remaja. 
Setiap remaja sebenarnya memiliki potensi untuk dapat mencapai kematangan kepribadian yang memungkinkan mereka dapat menghadapi tantangan hidup secara wajar di dalam lingkungannya, namun potensi ini tentunya tidak akan berkembang dengan optimal jika tidak ditunjang oleh faktor fisik dan faktor lingkungan yang memadai. Dalam pembentukan kepribadian seorang remaja, akan selalu ada beberapa faktor yang mempengaruhi yaitu faktor risiko dan faktor protektif. Faktor risiko ini dapat bersifat individual, konstekstual (pengaruh lingkungan), atau yang dihasilkan melalui interaksi antara individu dengan lingkungannya. Faktor risiko yang disertai dengan kerentanan psikososial, dan resilience pada seorang remaja akan memicu terjadinya gangguan emosi dan perilaku yang khas pada seorang remaja. Sedangkan faktor protektif merupakan faktor yang memberikan penjelasan bahwa tidak semua remaja yang mempunyai faktor risiko akan mengalami masalah perilaku atau emosi, atau mengalami gangguan tertentu. Rutter (1985) menjelaskan bahwa faktor protektif merupakan faktor yang memodifikasi, merubah, atau menjadikan respons seseorang menjadi lebih kuat menghadapi berbagai macam tantangan yang datang dari lingkungannya. Faktor protektif ini akan berinteraksi dengan faktor risiko dengan hasil akhir berupa terjadi tidaknya masalah perilaku atau emosi, atau gangguan mental kemudian hari.

Lemahnya emosi seseorang akan berdampak pada terjadinya masalah di kalangan remaja, misalnya bullying yang sekarang kembali mencuat di media. Kekerasan di sekolah ibarat fenomena gunung es yang nampak ke permukaan hanya bagian kecilnya saja. Akan terus berulang, jika tidak ditangani secara tepat dan berkesinambungan dari akar persoalannya.

Budaya bullying (kekerasan) atas nama senioritas masih terus terjadi di kalangan peserta didik. Karena meresahkan, pemerintah didesak segera menangani masalah ini secara serius. Bullying adalah suatu bentuk kekerasan anak (child abuse) yang dilakukan teman sebaya kepada seseorang (anak) yang lebih 'rendah' atau lebih lemah untuk mendapatkan keuntungan atau kepuasan tertentu. Biasanya bullying terjadi berulang kali. Bahkan ada yang dilakukan secara sistematis. Dari menjamurnya, kasus - kasus bullying yang ada di lembaga pendidikan di Indonesia khususnya lingkungan sekolah, penulis mengambil tema yang berkaitan dengan perilaku bullying di jenjang pendidikan.

Rumusan masalah dari makalah ini adalah 1) Apa yang dimaksud dengan bullying, 2) Apa jenis - jenis perbuatan bullying?, 3) Apa saja faktor yang menyebabkan perilaku bullying?, 
4) Apa saja dampak yang didapat akibat dari perilaku bullying?, dan 5) Bagaimana upaya pencegahan bullying

Tujuan penulisan dari makalah ini adalah : 1) Untuk mengetahui apa yang dimaksud dengan tindakan bullying dan jenis - jenis perbuatan yang termasuk dalam tindakan itu, 2) Untuk mengetahui faktor - faktor penyebab tindakan bullying serta dampak yang diakibatkan dari tindakan itu, dan 3) Untuk mengetahui bagaimana upaya mengatasi bullying.

\section{METODE PENELITIAN}

Metode penelitian yang digunakan adalah kajian pustaka atau studi kepustakaan yaitu berisi teori teori yang relevan dengan masalah - masalah penelitian. Adapun masalah pada penelitian ini adalah untuk mengetahui "Perilaku Bullying di Sekolah" Pada bagian ini dilakukan pengkajian mengenai konsep dan teori yang digunakan berdasarkan literatur yang tersedia, terutama dari artikel-artikel yang dipublikasikan dalam berbagai jurnal ilmiah. Kajian pustaka berfungsi untuk membangun konsep atau teori yang menjadi dasar studi dalam penelitian.

\section{PEMBAHASAN}

Definisi bullying merupakan sebuah kata serapan dari bahasa Inggris. Bullying berasal dari kata bully yang artinya penggertak, orang yang mengganggu orang yang lemah. Beberapa istilah dalam bahasa Indonesia yang seringkali dipakai masyarakat untuk menggambarkan fenomena bullying di antaranya adalah penindasan, penggencetan, perpeloncoan, pemalakan, pengucilan, atau intimidasi (Susanti, 2006).

Barbara Coloroso (2003:44) : "Bullying adalah tindakan bermusuhan yang dilakukan secara sadar dan disengaja yang bertujuan untuk menyakiti, seperti menakuti melalui ancaman agresi dan menimbulkan terror. Termasuk juga tindakan yang direncanakan maupun yang spontan bersifat nyata atau hampir tidak terlihat, dihadapan seseorang atau di belakang seseorang, mudah untuk diidentifikasi atau terselubung dibalik persahabatan, dilakukan oleh seorang anak atau kelompok anak.

Banyak para ahli yang mengemukakan pendapatnya mengenai bullying. Seperti pendapat Olweus (1993) dalam pikiran rakyat, 5 Juli 2007: "Bullying can consist of any action that is used to hurt another child repeatedly and without cause". Bullying merupakan perilaku yang ditujukan untuk melukai siswa lain secara terus-menerus dan tanpa sebab. Sedangkan menurut Rigby (2005; dalam Anesty, 2009) merumuskan bahwa "bullying" merupakan sebuah hasrat untuk 
menyakiti. Hasrat ini diperlihatkan dalam aksi, menyebabkan seseorang menderita. Aksi ini dilakukan secara langsung oleh seseorang atau sekelompok orang yang lebih kuat, tidak bertanggung jawab, biasanya berulang dan dilakukan dengan perasaan senang (Retno Astuti, 2008: 3).Riauskina, Djuwita, dan Soesetio (2001) mendefinisikan school bullying sebagai perilaku agresif kekuasaan terhadap siswa yang dilakukan berulang-ulang oleh seorang/kelompok siswa yang memiliki kekuasaan, terhadap siswa lain yang lebih lemah dengan tujuan menyakiti orang tersebut.

Beberapa ahli meragukan pengertian-pengertian di atas bahwa bullying hanya sekedar keinginan untuk menyakiti orang lain, mereka memandang bahwa "keinginan untuk menyakiti seseorang" dan "benar-be nar menyakiti seseorang" merupakan dua hal yang jelas berbeda. Oleh karena itu beberapa ahli psikologi menambahkan bahwa bullying merupakan sesuatu yang dilakukan bukan sekedar dipikirkan oleh pelakunya, keinginan untuk menyakiti orang lain dalam bullying selalu diikuti oleh tindakan negatif.

Dari berbagai definisi di atas dapat disimpulkan bahwa bullying merupakan serangan berulang secara fisik, psikologis, sosial, ataupun verbal, yang dilakukan dalam posisi kekuatan yang secara situasional didefinisikan untuk keuntungan atau kepuasan mereka sendiri. Bullying merupakan bentuk awal dari perilaku agresif yaitu tingkah laku yang kasar. Bisa secara fisik, psikis, melalui kata-kata, ataupun kombinasi dari ketiganya. Hal itu bisa dilakukan oleh kelompok atau individu. Pelaku mengambil keuntungan dari orang lain yang dilihatnya mudah diserang. Tindakannya bisa dengan mengejek nama, korban diganggu atau diasingkan dan dapat merugikan korban.

Barbara Coloroso (2006:47-50) membagi jenis-jenis bullying kedalam empat jenis, yaitu sebagai berikut:

1. Bullying secara verbal; perilaku ini dapat berupa julukan nama, celaan, fitnah, kritikan kejam, penghinaan, pernyataan-pernyataan yang bernuansa ajakan seksual atau pelecehan seksual, terror, surat-surat yang mengintimidasi, tuduhan-tuduhan yang tidak benar kasak-kusuk yang keji dan keliru, gosip dan sebagainya. Dari ketiga jenis bullying, bullying dalam bentuk verbal adalah salah satu jenis yang paling mudah dilakukan dan bullying bentuk verbal akan menjadi awal dari perilaku bullying yang lainnya serta dapat menjadi langkah pertama menuju pada kekerasan yang lebih lanjut. 
2. Bullying secara fisik; yang termasuk dalam jenis ini ialah memukuli, menendang, menampar, mencekik, menggigit, mencakar, meludahi, dan merusak serta menghancurkan barang-barang milik anak yang tertindas. Kendati bullying jenis ini adalah yang paling tampak dan mudah untuk diidentifikasi, namun kejadian bullying secara fisik tidak sebanyak bullying dalam bentuk lain. Remaja yang secara teratur melakukan bullying dalam bentuk fisik kerap merupakan remaja yang paling bermasalah dan cenderung akan beralih pada tindakantindakan kriminal yang lebih lanjut.

3. Bullying secara relasional; adalah pelemahan harga diri korban secara sistematis melalui pengabaian, pengucilan atau penghindaran. Perilaku ini dapat mencakup sikap-sikap yang tersembunyi seperti pandangan yang agresif, lirikan mata, helaan nafas, cibiran, tawa mengejek dan bahasa tubuh yang mengejek. Bullying dalam bentuk ini cenderung perilaku bullying yang paling sulit dideteksi dari luar. Bullying secara relasional mencapai puncak kekuatannya diawal masa remaja, karena saat itu tejadi perubahan fisik, mental emosional dan seksual remaja. Ini adalah saat ketika remaja mencoba untuk mengetahui diri mereka dan menyesuaikan diri dengan teman sebaya.

4. Bullying elektronik; merupakan bentuk perilaku bullying yang dilakukan pelakunya melalui sarana elektronik seperti komputer, handphone, internet, website, chatting room, e-mail, SMS dan sebagainya. Biasanya ditujukan untuk meneror korban dengan menggunakan tulisan, animasi, gambar dan rekaman video atau film yang sifatnya mengintimidasi, menyakiti atau menyudutkan. Bullying jenis ini biasanya dilakukan oleh kelompok remaja yang telah memiliki pemahaman cukup baik terhadap sarana teknologi informasi dan media elektronik lainnya.

Pada umumnya, anak laki-laki lebih banyak menggunakan bullying secara fisik dan anak wanita banyak menggunakan bullying relasional/emosional, namun keduanya sama-sama menggunakan bullying verbal. Perbedaan ini, lebih berkaitan dengan pola sosialisasi yang terjadi antara anak laki-laki dan perempuan (Coloroso, 2006:51).

Bullying dapat terjadi dimana saja, di perkotaan, pedesaan, sekolah negeri, sekolah swasta, di waktu sekolah maupun di luar waktu sekolah. Bullying terjadi karena interaksi dari berbagai faktor yang dapat berasal dari pelaku, korban, dan lingkungan dimana bullying tersebut terjadi.

Pada umumnya, anak-anak korban bullying memiliki salah satu atau beberapa faktor resiko berikut: 1) Dianggap "berbeda", misalnya memiliki ciri fisik tertentu yang mencolok seperti 
lebih kurus, gemuk, tinggi, atau pendek dibandingkan dengan yang lain, berbeda dalam status ekonomi, memiliki hobi yang tidak lazim, atau menjadi siswa/siswi baru, 2) Dianggap lemah atau tidak dapat membela dirinya.3) Memiliki rasa percaya diri yang rendah. 4) Kurang populer dibandingkan dengan yang lain, tidak memiliki banyak teman.

Sedangkan untuk pelaku bullying, Ada beberapa karakteristik anak yang memiliki kecenderungan lebih besar untuk menjadi pelaku bullying, yaitu mereka yang: 1) Peduli dengan popularitas, memiliki banyak teman, dan senang menjadi pemimpin diantara teman-temannya. Mereka dapat berasal dari keluarga yang berkecukupan, memiliki rasa percaya diri tinggi, dan memiliki prestasi bagus di sekolah. Biasanya mereka melakukan bullying untuk meningkatkan status dan popularitas di antara teman-teman mereka. 2) Pernah menjadi korban bullying. Mereka juga mungkin mengalami kesulitan diterima dalam pergaulan, kesulitan dalam mengikuti pelajaran di sekolah, mudah terbawa emosi, merasa kesepian dan mengalami depresi. 3)bMemiliki rasa percaya diri yang rendah, atau mudah dipengaruhi oleh teman-temannya. Mereka dapat menjadi pelaku bullying karena mengikuti perilaku teman-teman mereka yang melakukan bullying, baik secara sadar maupun tidak sadar.

Dalam penelitian Riauskina, Djuwita, dan Soesetio, (2005) alasan seseorang melakukan bullying adalah karena korban mempunyai persepsi bahwa pelaku melakukan bullying karena tradisi, balas dendam karena dia dulu diperlakukan sama (menurut korban laki-laki), ingin menunjukkan kekuasaan, marah karena korban tidak berperilaku sesuai dengan yang diharapkan, mendapatkan kepuasan (menurut korban laki - laki ), dan iri hati (menurut korban perempuan). Adapun korban juga mempersepsikan dirinya sendiri menjadi korban bullying karena penampilan yang menyolok, tidak berperilaku dengan sesuai, perilaku dianggap tidak sopan, dan tradisi.

Menurut psikolog Seto Mulyadi, Bullying disebabkan karena : 1)nMenurutnya, saat ini remaja di Indonesia penuh dengan tekanan. Terutama yang datang dari sekolah akibat kurikulum yang padat dan teknik pengajaran yang terlalu kaku. Sehingga sulit bagi remaja untuk menyalurkan bakat nonakademisnya Penyalurannya dengan kejahilan-kejahilan dan menyiksa. 2) Budaya feodalisme yang masih kental di masyarakat juga dapat menjadi salah satu penyebab bullying sebagai wujudnya adalah timbul budaya senioritas, yang bawah harus menurut denganyang atas. 
Perilaku bullying pada anak, disebabkan banyak hal, menurut Mc Dougall dalam diri setiap orang terdapat instink untuk menyerang dan berkelahi. Dorongan dari naluri ini yaitu rasa marah karena suatu hal terutama karena merasa terancam atau kebutuhannya tidak terpenuhi. Jadi ia melakukan bullying untuk melepaskan emosi yang ia pendam. Teori Belajar Sosial (Social Learning), Teori belajar sosial yang dicetuskan oleh Bandura menekankan bahwa kondisi lingkungan dapat memberikan dan memelihara respon-respon kekerasan pada diri seseorang. Asumsi dasar dari teori ini yaitu sebagian besar tingkah laku individu diperoleh dari hasil belajar melalui pengamatan yang dilakukan anak atas tingkah laku yang ditampilkan oleh individuindividu lain yang menjadi model, yang biasanya adalah orang terdekat di lingkungannya seperti orang tua. Anak-anak yang melihat model orang dewasa melakukan kekerasan secara kosisten ia akan memiliki kecenderungan berperilaku kekerasan bila dibandingkan dengan anak-anak yang melihat model orang dewasa yang tidakmelakukan kekerasan.

Pengaruh media, tayangan televisi yang bebas di Indonesia, dari film kartun hiburan anakanak, adegan di sinetron, berita kekerasan di daerah lain yang dapat dilihat secara bebas oleh anak-anak dapat memberikan mereka contoh perilaku kekrasan yang akan ia praktekkan di sekolah. Atau bila ia melihat hal itu secara terus menerus maka keempatiannya terhadap perilaku kekerasan itu makin memudar, ia akan menganggap kekerasan itu adalah hal yang wajar.

Bullying memiliki berbagai dampak negatif yang dapat dirasakan oleh semua pihak yang terlibat di dalamnya, baik pelaku, korban, ataupun orang-orang yang menyaksikan tindakan bullying. Hasil studi yang dilakukan National Youth Violence Prevention Resource Center Sanders (2003; dalam Anesty, 2009) menunjukkan bahwa bullying dapat membuat remaja merasa cemas dan ketakutan, mempengaruhi konsentrasi belajar di sekolah dan menuntun mereka untuk menghindari sekolah. Bila bullying berlanjut dalam jangka waktu yang lama, dapat mempengaruhi self-esteem siswa, meningkatkan isolasi sosial, memunculkan perilaku menarik diri, menjadikan remaja rentan terhadap stress dan depreasi, serta rasa tidak aman. Dalam kasus yang lebih ekstrim, bullying dapat mengakibatkan remaja berbuat nekat, bahkan bisa membunuh atau melakukan bunuh diri (commited suicide).

Coloroso (2006) mengemukakan bahayanya jika bullying menimpa korban secara berulang-ulang. Konsekuensi bullying bagi para korban, yaitu korban akan merasa depresi dan marah, Ia marah terhadap dirinya sendiri, terhadap pelaku bullying, terhadap orang-orang di sekitarnya dan terhadap orang dewasa yang tidak dapat atau tidak mau menolongnya. Hal 
tersebut kemudan mulai mempengaruhi prestasi akademiknya. Berhubung tidak mampu lagi muncul dengan cara-cara yang konstruktif untuk mengontrol hidupnya, ia mungkin akan mundur lebih jauh lagi ke dalam pengasingan.

Terkait dengan konsekuensi bullying, penelitian Banks (1993, dalam Northwest Regional Educational Laboratory, 2001; dan dalam Anesty, 2009) menunjukkan bahwa perilaku bullying berkontribusi terhadap rendahnya tingkat kehadiran, rendahnya prestasi akademik siswa, rendahnya self-esteem, tingginya depresi, tingginya kenakalan remaja dan kejahatan orang dewasa. Dampak negatif bullying juga tampak pada penurunan skor tes kecerdasan (IQ) dan kemampuan analisis siswa. Berbagai penelitian juga menunjukkan hubungan antara bullying dengan meningkatnya depresi dan agresi.

Dampak bagi pelaku, Sanders (2003; dalam Anesty, 2009) National Youth Violence Prevention mengemukakan bahwa pada umumnya, para pelaku ini memiliki rasa percaya diri yang tinggi dengan harga diri yang tinggi pula, cenderung bersifat agresif dengan perilaku yang pro terhadap kekerasan, tipikal orang berwatak keras, mudah marah dan impulsif, toleransi yang rendah terhadap frustasi. Para pelaku bullying ini memiliki kebutuhan kuat untuk mendominasi orang lain dan kurang berempati terhadap targetnya. Apa yang diungkapkan tersebut sesuai dengan yang dikemukakan oleh Coloroso (2006:72) mengungkapkan bahwa siswa akan terperangkap dalam peran pelaku bullying, tidak dapat mengembangkan hubungan yang sehat, kurang cakap untuk memandang dari perspektif lain, tidak memiliki empati, serta menganggap bahwa dirinya kuat dan disukai sehingga dapat mempengaruhi pola hubungan sosialnya di masa yang akan datang.

Dengan melakukan bullying, pelaku akan beranggapan bahwa mereka memiliki kekuasaan terhadap keadaan. Jika dibiarkan terus-menerus tanpa intervensi, perilaku bullying ini dapat menyebabkan terbentuknya perilaku lain berupa kekerasan terhadap anak dan perilaku kriminal lainnya.

Dampak bagi siswa lain yang menyaksikan bullying (bystanders). Jika bullying dibiarkan tanpa tindak lanjut, maka para siswa lain yang menjadi penonton dapat berasumsi bahwa bullying adalah perilaku yang diterima secara sosial. Dalam kondisi ini, beberapa siswa mungkin akan bergabung dengan penindas karena takut menjadi sasaran berikutnya dan beberapa lainnya mungkin hanya akan diam saja tanpa melakukan apapun dan yang paling parah mereka merasa tidak perlu menghentikannya. 
Selain dampak-dampak bullying yang telah dipaparkan di atas, penelitian- penelitian yang dilakukan baik di dalam maupun luar negeri menunjukkan bahwa bullying mengakibatkan dampak-dampak negatif sebagai berikut:

Gangguan psikologis, misalnya rasa cemas berlebihan, kesepian (Rigby K. 2003). Konsep diri sosial korban bullying menjadi lebih negatif karena korbam merasa tidak diterima oleh teman-temannya, selain itu dirinya juga mempunyai pengalaman gagal yang terus-menerus dalam membina pertemanan, yaitu di bully oleh teman dekatnya sendiri (Ratna Djuwita, dkk , 2005).

Korban bullying merasakan stress, depresi, benci terhadap pelaku, dendam, ingin keluar sekolah, merana, malu, tertekan, terancam, bahkan ada yang menyilet-nyilet tangannya (Ratna Djuwita, dkk , 2005). 1. Membenci lingkungan sosialnya, enggan ke sekolah (Forero et all.1999). 2) Keinginan untuk bunuh diri (Kaltiala-Heino, 1999). 3) Kesulitan konsentrasi; rasa takut berkepanjangan dan depresi (Bond, 2001). 5) Cenderung kurang empatik dan mengarah ke psikotis (Banks R., 1993). 6) Pelaku bullying yang kronis akan membawa perilaku itu sampai dewasa, akan berpengaruh negatif pada kemampuan mereka untuk membangun dan memelihara hubungan baik dengan orang lain. 7) Korban akan merasa rendah diri, tidak berharga (Rigby, K, 1999). 8) Gangguan pada kesehatan fisik: sakit kepala, sakit tenggorokan, flu, batuk- batuk, gatal-gatal, sakit dada, bibir pecah-pecah (Rigby, K, 2003).

Berdasarkan paparan di atas, dapat kita lihat bahwa bullying memiliki dampak yang luas terhadap semua orang yang terlibat di dalamnya, baik secara langsung maupun tidak langsung, dalam jangka pendek dan dalam jangka panjang.

Dalam rangka mencegah bullying, banyak pihak telah menjalankan program dan kampanye anti bullying di sekolah-sekolah, baik dari pihak sekolah sendiri, maupun organisasi-organisasi lain yang berhubungan dengan anak. Namun, pada nyatanya, bullying masih kerap terjadi di sekolah-sekolah di Indonesia, seperti yang dapat kita amati melalui kejadian baru-baru ini di salah satu SMA swasta yang disebutkan di awal tulisan ini.

Lalu apakah yang dapat kita sebagai perorangan lakukan untuk memerangi bullying? Pertama. Membantu anak-anak mengetahui dan memahami bullying. Dengan menambah pengetahuan anak-anak mengenaibullying, mereka dapat lebih mudah mengenali saat bullying menimpa mereka atau orang-orang di dekat mereka. Selain itu anak-anak juga perlu dibekali dengan pengetahuan untuk menghadapi bullying dan bagaimana mencari pertolongan. 
Hal-hal yang dapat dilakukan untuk meningkatkan pemahaman anak mengenai bullying, diantaranya: 1) Memberitahu pada anak bahwa bullying tidak baik dan tidak dapat dibenarkan dengan alasan maupun tujuan apapun. Setiap orang layak diperlakukan dengan hormat, apapun perbedaan yang mereka miliki. 2) Memberitahu pada anak mengenai dampakdampak bullying bagi pihak-pihak yang terlibat maupun bagi yang menjadi "saksi bisu”.

Kedua. Memberi saran mengenai cara-cara menghadapi bullying. Setelah diberikan pemahaman mengenai bullying, anak-anak juga perlu dibekali pengetahuan dan keterampilan ketika mereka menjadi sasaran dari bullying agar dapat menghadapinya dengan aman tanpa menggunakan cara-cara yang agresif atau kekerasan, yang dapat semakin memperburuk keadaan. Cara-cara yang dapat digunakan, misalnya dengan mengabaikan pelaku, menjauhi pelaku, atau menyampaikan keberatan mereka terhadap pelaku dengan terbuka dan percaya diri. Mereka juga dapat menghindari bullying dengan berada di sekitar orang-orang dewasa, atau sekelompok anak-anak lain. Apabila anak menjadi korban bullying dan cara-cara di atas sudah dilakukan namun tidak berhasil, mereka sebaiknya didorong untuk menyampaikan masalah tersebut kepada orang-orang dewasa yang mereka percayai, baik itu guru di sekolah maupun orangtua atau anggota keluarga lainnya di rumah.

Ketiga. Membangun hubungan dan komunikasi dua arah dengan anak. Biasanya pelaku bullying akan mengancam atau mempermalukan korban bila mereka mengadu kepada orang lain, dan hal inilah yang biasanya membuat seorang korban bullying tidak mau mengadukan kejadian yang menimpa mereka kepada orang lain. Oleh karena itu, sangat penting untuk senantiasa membangun hubungan dan menjalin komunikasi dua arah dengan anak, agar mereka dapat merasa aman dengan menceritakan masalah yang mereka alami dengan orangorang terdekat mereka, dan tidak terpengaruh oleh ancaman-ancaman yang mereka terima dari para pelaku bullying. Dalam kehidupan masa kini yang serba sibuk dan penuh aktivitas, semakin sulit bagi para orangtua dan anggota keluarga untuk

Keempat, mendorong mereka untuk tidak menjadi "saksi bisu" dalam kasus bullying. Berdasarkan sebuah penelitian yang dilakukan pada anak-anak sekolah dasar di Kanada, sebagian besar kasus bullying dapat dihentikan dalam 10 detik setelah kejadian tersebut berlangsung berkat campur tangan saksi -anak anak lain yang hadir saat kejadian tersebut berlangsung- misalnya dengan membela korban bullying melalui kata-kata ataupun secara fisik (memisahkan korban dengan pelaku). Anak-anak yang menyaksikan kasus bullying juga dapat 
membantu dengan cara: 1) Menemani atau menjadi teman bagi korban bullying, misalnya dengan mengajak bermain atau berkegiatan bersama. 2) Menjauhkan korban dari situasi-situasi yang memungkinkan ia mengalami bullying. 3) Mengajak korban bicara mengenai perlakuan yang ia terima, mendengarkan ia bercerita dan mengungkapkan perasaannya. 4) Apabila dibutuhkan, membantu korban mengadukan permasalahannya kepada orang dewasa yang dapat dipercaya.

Kelima. Membantu anak menemukan minat dan potensi mereka. Dengan mengetahui minat dan potensi mereka, anak-anak akan terdorong untuk mengembangkan diri dan bertemu serta berteman dengan orang-orang yang memiliki minat yang sama. Hal ini akan meningkatkan rasa percaya diri dan mendukung kehidupan sosial mereka sehingga membantu melindungi mereka dari bullying.

Terhadap anak-anak yang berisiko terkena bullying atau menjadi korban bullying, lakukan langkah berikut ini : 1) Jangan membawa barang-barang mahal atau uang berlebihan. Merampas, merusak, atau menyandera barang-barang korban adalah tindakan yang biasanya dilakukan pelaku bullying. Oleh karena itu, sebisa mungkin jangan beri mereka kesempatan membawa barang mahal atau uang yang berlebihan ke sekolah. 2) Jangan sendirian. Pelaku bullying melihat anak yang menyendiri sebagai "mangsa" yang potensial. Oleh karena itu, jangan sendirian di dalam kelas, di lorong sekolah, atau tempat-tempat sepi lainnya. Kalau memungkinkan, beradalah di tempat di mana guru atau orang dewasa lainnya dapat melihat. Akan lebih baik lagi, jika anak tersebut bersama-sama dengan teman, atau mencoba berteman dengan anak-anak penyendiri lainnya. 3) Jangan cari gara-gara dengan pelaku bullying. 4) Jika anak tersebut suatu saat terperangkap dalam situasi bullying, kuncinya adalah tampil percaya diri. 5) Jangan memperlihatkan diri seperti orang yan lemah atau ketakutan. 6) Harus berani melapor pada orang tua, guru, atau orang dewasa lainnya yang dipercayainya. Ajaklah anak tersebut untuk berani bertindak dan mencoba

Keenam. Memberi teladan lewat sikap dan perilaku. Sebaik dan sebagus apapun slogan, saran serta nasihat yang mereka dapatkan, anak akan kembali melihat pada lingkungan mereka untuk melihat sikap dan perilaku seperti apa yang diterima oleh masyarakat. Walaupun tidak terlihat demikian, anak-anak juga memerhatikan dan merekam bagaimana orang dewasa mengelola stres dan konflik, serta bagaimana mereka memperlakukan orang-orang lain di sekitar mereka. Apabila kita ingin ikut serta dalam memerangi bullying, hal paling sederhana yang dapat 
kita lakukan adalah dengan tidak melakukan bullying atau hal-hal lain yang mirip dengan bullying. Disadari maupun tidak, orang dewasa juga dapat menjadi korban ataupun pelaku bullying, misalnya dengan melakukan bullying di tempat kerja, ataupun melakukan kekerasan verbal terhadap orang-orang di sekitar kita.

Pencegahan buat anak yang menjadi korban bullying: 1) Bekali anak dengan kemampuan untuk membela dirinya sendiri, terutama ketika tidak ada orang dewasa/ guru/ orang tua yang berada di dekatnya. Ini berguna untuk pertahanan diri anak dalam segala situasi mengancam atau berbahaya, tidak saja dalam kasus bullying. Pertahanan diri ini dapat berbentuk fisik dan psikis. Pertahanan diri Fisik : bela diri, berenang, kemampuan motorik yang baik (bersepeda, berlari), kesehatan yang prima. Pertahanan diri Psikis : rasa percaya diri, berani, berakal sehat, kemampuan analisa sederhana, kemampuan melihat situasi (sederhana), kemampuan menyelesaikan masalah. 2) Bekali anak dengan kemampuan menghadapi beragam situasi tidak menyenangkan yang mungkin ia alami dalam kehidupannya. Untuk itu, selain kemampuan mempertahankan diri secara psikis. Maka yang diperlukan adalah kemampuan anak untuk bertoleransi terhadap beragam kejadian. Sesekali membiarkan (namun tetap mendampingi) anak merasakan kekecewaan, akan melatih toleransi dirinya. 3) Walau anak sudah diajarkan untuk mempertahankan diri dan dibekali kemampuan agar tidak menjadi korban tindak kekerasan, tetap beritahukan anak kemana ia dapat melaporkan atau meminta pertolongan atas tindakan kekerasan yang ia alami (bukan saja bullying). Terutama tindakan yang tidak dapat ia tangani atau tindakan yang terus berlangsung walau sudah diupayakan untuk tidak terulang. 4) Upayakan anak mempunyai kemampuan sosialisasi yang baik dengan sebaya atau dengan orang yang lebih tua. Dengan banyak berteman, diharapkan anak tidak terpilih menjadi korban bullying karena : a). Kemungkinan ia sendiri berteman dengan pelaku, tanpa sadar bahwa temannya pelaku bullying pada teman lainnya. B) Kemungkinan pelaku enggan memilih anak sebagai korban karena si anak memiliki banyak teman yang mungkin sekali akan membela si anak. c) Sosialisasi yang baik dengan orang yang lebih tua, guru atau pengasuh atau lainnya, akan memudahkan anak ketika ia mengadukan tindakan kekerasan yang ia alami.

Penanganan buat anak yang menjadi pelaku Bullying: 1). Segera ajak anak bicara mengenai apa yang ia lakukan. Jelaskan bahwa tindakannya merugikan diri dan orang lain. Upayakan bantuan dari tenaga ahlinya agar masalah tertangani dengan baik dan selesai dengan tuntas. 2) Cari penyebab anak melakukan hal tersebut. Penyebab menjadi penentu penanganan. 
Anak yang menjadi pelaku karena rasa rendah diri tentu akan ditangani secara berbeda dengan pelaku yang disebabkan oleh dendam karena pernah menjadi korban.Demikian juga bila pelaku disebabkan oleh agresifitasnya yang berbeda. 3)Posisikan diri untuk menolong anak dan bukan menghakimi anak.

\section{PENUTUP}

Kesimpulan dari makalah ini adalah bullying adalah suatu tindakan negatif yang dilakukan secara berulang-ulang dimana tindakan tersebut sengaja dilakukan dengan tujuan untuk melukai dan memnuat seseorang merasa tidak nyaman. Pemahaman moral adalah pemahaman individu yang menekankan pada alasan mengapa suatu tindakan dilakukan dan bagaimana seseorang berpikir sampai pada keputusan bahwa sesuatu adalah baik atau buruk. Pemahaman moral bukan tentang apa yang baik atau buruk, tetapi tentang bagaimana seseorang berpikir sampai pada keputusan bahwa sesuatu adalah baik atau buruk. Peserta didik dengan pemahaman moral yang tinggi akan memikirkan dahulu perbuatan yang akan dilakukan sehingga tidak akan melakukan menyakiti atau melakukan bullying kepada temannya.

Selain itu, keberhasilan remaja dalam proses pembentukan kepribadian yang wajar dan pembentukan kematangan diri membuat mereka mampu menghadapi berbagai tantangan dan dalam kehidupannya saat ini dan juga di masa mendatang. Untuk itu mereka seyogyanya mendapatkan asuhan dan pendidikan yang menunjang untuk perkembangannya.

Dari Kesimpulan diatas dapat disarankan 1) hendaknya pihak sekolah proaktif dengan membuat program pengajaran keterampilan sosial, problemsolving, manajemen konflik, dan pendidikan karakter. 2) Hendaknya guru memantau perubahan sikap dan tingkah laku siswa di dalam maupun di luar kelas; dan perlu kerjasama yang harmonis antara guru BK, guru-guru mata pelajaran, serta staf dan karyawan sekolah. 3) Sebaiknya orang tua menjalin kerjasama dengan pihak sekolah untuk tercapainya tujuan pendidikan secara maksimal tanpa adanya tindakan bullying antar pelajar di sekolah.

\section{DAFTAR PUSTAKA}

Ali Mohamad dan Asrori Mohamad, (2006). Psikologi Remaja Perkembangan Peserta Didik. Jakarta : Bumi Aksara.

Assegaf, Abd. Rahman.( 2004). Pendidikan Tanpa Kekerasan : Tipologi Kondisi, Kasus dan Konsep. Yogya: Penerbit Tiara Wacana. 
Astuti, P.R. (2008). Meredam Bullying: 3 cara efektif mengatasi kekerasan pada anak. Jakarta: PT. Grasindo.

Evertson M Carolyn.(2001).Manajemen Kelas Untuk Guru Sekolah Dasar. Jakarta: Pranada media Group.

Sulfemi, W. B. (2009). Modul Pembelajaran Pendidikan Pancasila dan Kewarganegaraan. Bogor: STKIP Muhammadiyah Bogor, 1, 1-49.

Sulfemi, Wahyu Bagja. (2016). Modul Pembelajaran Ilmu Sosial dan Budaya Dasar. Bogor : STKIP Muhammadiyah Bogor.

Sulfemi, Wahyu Bagja. (2017). Korelasi Penilaian Guru Terhadap Gaya Kepemimpinan Asertif Kepala Sekolah Dengan Kinerja Guru Di SMPN 01 Jasinga Kabupaten Bogor. Lingua : Jurnal ilmiah Kajian Pendidikan Bahasa dan Sastra Indonesia. 3 (1) 201 7. $90-100$

Sulfemi, W. B. (2018). Pengaruh Disiplin Ibadah Sholat, Lingkungan Sekolah, dan Intelegensi Terhadap Hasil Belajar Peserta Didik Mata Pelajaran Pendidikan Agama Islam. EDUKASI: Jurnal Penelitian Pendidikan Agama dan Keagamaan, 16 (2).

Sulfemi, Wahyu Bagja dan Hilga Minati. (2018). Meningkatkan Hasil Belajar Peserta Didik Kelas 3 SD Menggunakan Model Picture And Picture dan Media Gambar Seri. JPSD. 4 (2), 228- 242.

Sulfemi, W. B., \& Yuliana, D. (2019). Penerapan Model Pembelajaran Discovery Learning Meningkatkan Motivasi Dan Hasil Belajar Pendidikan Kewarganegaraan. Jurnal Rontal Keilmuan Pancasila dan Kewarganegaraan, 5(1), 17-30.

Sulfemi, Wahyu Bagja. (2019). Bergaul Tanpa Harus Menyakiti. Bogor : Visi Nusantara Maju.

Sulfemi, Wahyu Bagja. (2019). Menanggulangi Prilaku Bullying Di Sekolah. Bogor : Visi Nusantara Maju.

Sulfemi, Wahyu Bagja dan Yuliani, Nunung. (2019). Model Pembelajaran Contextual Teaching And Learning (CTL) Berbantu Media Miniatur Lingkungan Untuk Meningkatkan Hasil Belajar IPS. Edunomic : Jurnal Ilmiah Pendidikan Ekonomi Fakultas Keguruan Dan Ilmu Pendidikan. 7 ( 2) . 73-84

Sulfemi, W. B. (2019). Model Pembelajaran Kooperatif Mind Mapping Berbantu Audio Visual Dalam Meningkatkan Minat, Motivasi dan Hasil Belajar IPS. Jurnal PIPSI (Jurnal Pendidikan IPS Indonesia), 4(1), 13-19.

Sulfemi, W. B. (2019). Manajemen Pendidikan Berbasis Multi Budaya. Bogor : STKIP Muhammadiyah Bogor. 
